\title{
Positioning of the knot in the steel wire in relation to the tooth and the Erich bars. Technical note
}

Gabriela Maffeis D'Assumpção SIMÕES ${ }^{1}$

Rogerio Henrique BERARDI ${ }^{2}$

José Lineu Pereira OGOSHI ${ }^{3}$

Fernando Kendi HORIKAWA 4

Iron Ricardo Machado SNIDEI ${ }^{5}$

Elio Hitoshi SHINOHARA ${ }^{6}$

'Dental student. Dental School-Universidade Ibirapuera-Unib. São Paulo, Brazil

${ }^{2} D D S$, Dental implant Specialist. MSc Student. Post graduate Program. Dental School-lbirapuera University-Unib. Sao Paulo, Brazil

${ }^{3}$ DDS, OMFS Specialist. MSc Student. Post graduate Program. Dental School -ibirapuera University-Unib. Sao Paulo, Brazil

${ }^{4} \mathrm{PhD}$, Associate Surgeon. Department of Oral and Maxillofacial Surgery. Hospital Regional de Osasco SUS/SP. Osasco, Brazil

${ }^{5} D D S, M D$, Chair. Department of Oral and Maxillofacial Surgery. Hospital Regional de Osasco SUS/SP. Osasco, Brazil

${ }^{6} D D S, P h D$, Assistant Surgeon. Department of Oral and Maxillofacial Surgery. Hospital Regional de Osasco SUS/SP, Brazil

\section{Abstract}

Erich bar is a basic technique for restoring occlusal alignment in patients with facial fractures. Although this method is used worldwide, there is no description of what is the best way to stabilize the bar that should be anchored tooth to tooth with steel wire. We describe the method of stabilizing the bar of current use in our Service. We indicate the use of this technique because it stabilizes the bar and, in our opinion, it reduces the need to twist the knots during the patient's return.

Descriptors: Fracture Fixation; Facial Injuries; Mandible.

\section{INTRODUCTION}

Erich bar is a basic technique for restoring occlusal alignment in patients with facial fractures. Although this method is used worldwide, there is no description of what is the best way to stabilize the bar that should be anchored tooth to tooth with steel wire. We describe the method of stabilizing the bar of current use in our Service. We indicate the use of this technique because it stabilizes the bar and, in our opinion, it reduces the need to twist the knots during the patient's return.

TECHNIQUE

We separate the dental arches in four quadrants. The steel wire is always passed in the apical position medially, and the knot presses the bar against the tooth crown, which increases its stability and immobility (Figure 1).

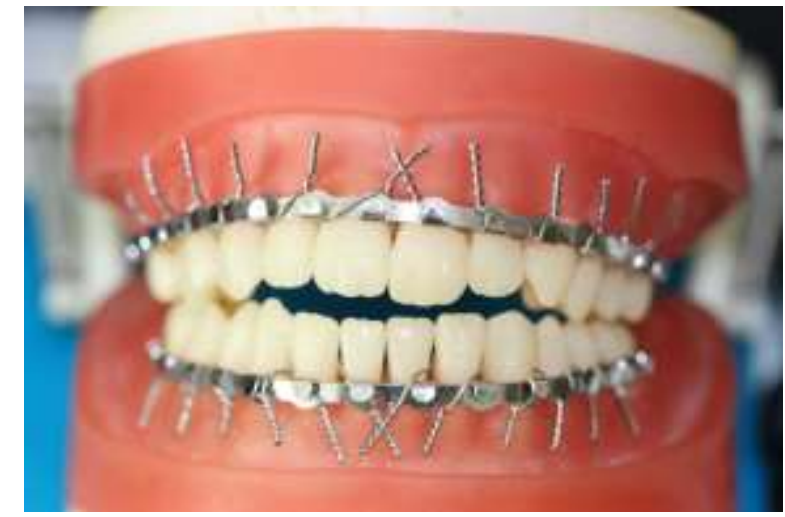

Figure 1. Dental model showing erich bar anchored with steel wire, with the wire always passing to apical in the medial portion.

We always pull the needle holder from back to front and from coronal to apical (Figure 2).

This way we were able to install the bar in a standardized way and clinically it was detected that the steel wires loosen less, which requires less maintenance and knot tightening (Figure 3).

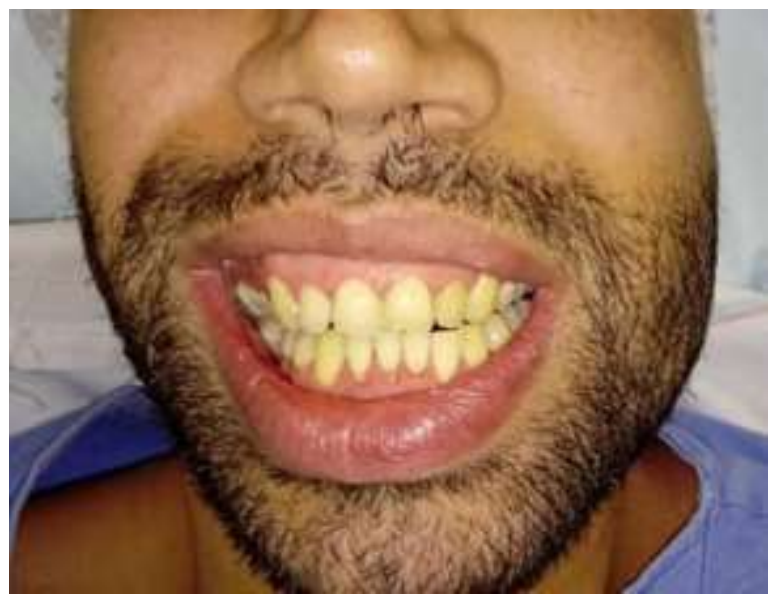

Figure 2. Patient with mandibular fracture, presenting loss of occlusion.

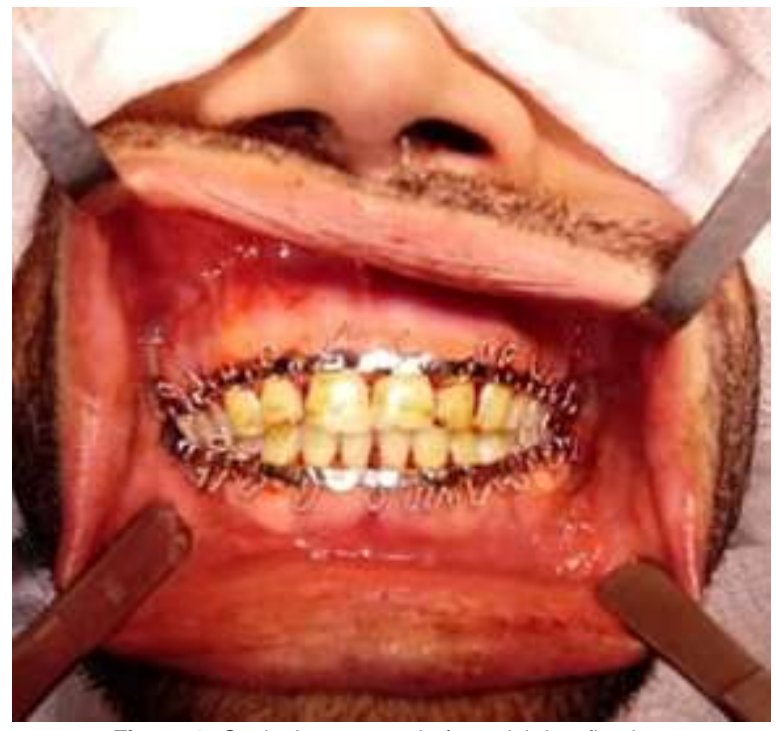

Figure 3. Occlusion restored after erich bar fixation.

REFERENCES

1. Pathak $P$, Thomas $S$, Bhargava D, Beena S. A prospective comparative clinical study on modified screw retained arch bar (SRAB) and conventional Erich's arch bar (CEAB). Oral Maxillofac Surg. 2019;23(3):285-89. 
2. Johnson AW. Dental occlusion ties: A rapid, safe, and non-invasive maxillo-mandibular fixation technology. Laryngoscope Investig Otolaryngol. 2017;2(4):178-83.

3. Abbasi AJ, Parvin M. New method of arch bar fixation. $\mathrm{Br} J$ Oral Maxillofac Surg. 2017; 55(6):631-32.

\section{CONFLICTS OF INTERESTS}

The authors declare no conflicts of interests.

\section{CORRESPONDING AUTHOR}

Elio H Shinohara DDS, PhD.

Dept Oral and Maxillofac Surg

Hospital Regional de Osasco SUS/SP

Rua Ari Barroso, 355. Presidente Altino.

ZIP Code: 06216-240 Osasco-SP, Brazil

e-mail: elioshinohara@yahoo.com.br

Received 12/10/2020

Accepted 23/10/2020 